\author{
$2^{\text {nd }}$ International Academic Conference on \\ HUMANIZING THE FIRM AND THE MANAGEMENT PROFESSION \\ IESE Business School, University of Navarre \\ June 28-30, 2011 - Barcelona, Spain
}

\title{
PARTICIPATING IN THE COMMON GOOD OF THE FIRM
}

Alejo José G. Sison, Joan Fontrodona and Ignacio Ferrero

\begin{abstract}
Previously we have defined the common good of the firm as work-in-common, insofar as it provides, above all, an opportunity to develop knowledge, skills, virtues and meaning (work as praxis), and secondly, inasmuch as it produces goods and services to satisfy society's needs and wants (work as poiesis). We would now like to focus on the participatory aspect of this common good. To do so, we will have to identify the different members of the firm as a community, as citizens of the corporate polity. Afterwards, we will explore how these different members can and should participate in the firm's common good.
\end{abstract}

\section{The Common Good of the Firm}

The generic common good of the firm is the production of goods and services in which human beings participate through work. From an Aristotelian viewpoint, this is the good of the firm as an intermediate association and of each of its constituents. Insofar as the firm achieves this, it fulfils its purpose: it becomes a "good firm", one that is well-governed and that makes its members good. In the same way that citizens participate in the common good of the polis by exercising citizenship, the members of the firm participate in its common good through work. 
This idea of the embeddedness of the human good, firstly, in the firm as an intermediate institution, and secondly, within the wider political community, such that there need not be conflict between the two, but harmony and integration, is very similar to a view expressed by Solomon. He denounced the "schism” commonly introduced between business and the rest of one's life, when for Aristotle, they were "supposed to fit together in a coherent whole" (Solomon 1992: 322). What's more, Solomon continues, "[a]ccording to Aristotle, one has to think of oneself as a member of the larger community, the Polis, and strive to excel, to bring out what was best in ourselves and our shared enterprise. What is best in us — our virtues - are in turn defined by that larger community, and there is therefore no ultimate split...” (Solomon 1992: 322). We extend this idea by advancing work in common, insofar as it provides an opportunity for developing the virtues, as an activity that enables the link between the of good of the firm and the good of the polity.

Let us recall Aquinas’ analogy between God, as the extrinsic, ontological and contemplative common good, and flourishing or eudaimonia, as the intrinsic, social and practical common good. From this Thomistic perspective, the common good of the firm may be described — like eudaimonia for the polity— as intrinsic, social and practical. "Practical" because it refers to work, an activity to be performed, not just an object of speculation; "social” because work in common depends on the effort of a community, acting coordinatedly or in unison; and "intrinsic" because such participatory work is essential to the firm and cannot exist independently. If one were capable, by himself, of manufacturing a car, there would be no need, perhaps, of constituting a car manufacturing firm. But since that is practically impossible, at least on a large scale, due to limitations of time, financial resources, specialized talent, and so forth, people 
form a corporation. The pooling together of people and resources is, above all, for the purpose of productive work that cannot be carried out except in a participatory manner. Work in common then becomes the reason for being of the firm, what brings together all the people and resources in the production process; it is the end that they all have in common.

Again, drawing inspiration from Aquinas, we could describe the common good of the firm as an "integral whole" consisting of "formal” and "actual" parts, on the one hand, and "material” and "potential” parts, on the other. Workers as firm members are "formal" and "actual" parts because as free, intelligent and unique actors, their contribution to the common productive process cannot, to a significant extent, be replaced by others. This is another way of saying that, in a sense, none of the workers in a firm that has reached its common good is expendable, and that the common productive process and its results would not be the same without every one of them. Each worker makes a difference to the whole. The "material" and "potential" parts of the common good of the firm refer to the sum total of nonpersonal conditions, resources, instruments and means that make participatory work possible. Unlike the workers, financial capital or equipment, for instance, can easily be substituted in their contribution to the productive process by any similar amount of money or machinery. But this doesn't mean that they are any less necessary for the common good of the firm, since certainly, it cannot be attained without these materials. The common good of the firm requires just the right people and just the right productive resources.

The common good of the firm does not refer, at first hand, to the goods and services produced in themselves. It does not lie primarily in things, but in their 
production by a group. Work in common, then, is the reason people come together in the firm. Certainly, their activity does not take place in a void and material resources are needed. But people share more directly in the work itself than in the products that are the outcome this work. For instance, maintenance personnel at a university do not deliver lectures, which are the primary service the university delivers, but they participate in the collective effort that allows the university through its professors to teach. Teaching is directly incumbent only upon professors, not on the maintenance personnel. Participatory work as the common good of the firm does not require that everyone does the same thing, but that there be a unity of end or purpose. Similarly, in a car manufacturing plant, although only assembly line workers are engaged directly in making the product, nonetheless, without those in the finance department, for example, vehicles could not be produced. This is what we mean when we say that a firm's members participate more in the work in common than in the goods and services that the firm produces.

We emphasize production rather than the resulting goods and services because the common good of the firm has to be an activity or practice: work in common. Work consists in a purposive and free human act or "voluntary act” (Nicomachean Ethics, henceforth, NE 1111a), that is, one arising from the will and endowed with an “intention” or knowledge of its end or aim. Work designates that class of human or "voluntary acts" that are productive actions (NE 1139a-b). This means that work changes or transforms objects, thereby introducing certain novelty in the world. Work thus differs from theory, speculation or abstract thought which simply describes, mirrors or reflects what is found in reality without changing it. In summary, work is something that we perform, and not only something that we think about. The performance of work 
engages both our will and intellect while we change or transform concrete material realities, producing something that at first wasn't there, or something that already existed but differently.

Work is a sort of transformative activity, and transformative activities are generally of two kinds: making (poiesis) or doing (praxis) (Politics, henceforth, Pltcs 1254a). Whenever human beings act on matter, two different results can be expected. One is objective, existing independently from the agent and externally observable. The other is subjective, inhering in the agent himself and inseparable from him. Despite not being directly observable, the subjective result nevertheless holds certain consequences in the agent's actions. In the case of the assembly line worker, the objective result is the car itself, whereas for the university professor, the lectures. The subjective results would be the manual or mental skills, the moral excellences or virtues and the meanings that each worker develops or acquires while performing his function. The car factory worker who strives to do his work with perfection and attention to detail gains in the virtue of industriousness, while the university professor who perseveres in study and research advances in the virtue of diligence.

Work in a firm also serves as an occasion for meaningful exchange, relationship and encounter among human beings. Unfortunately, we cannot at present go in depth in the empirical, sociohistorical and conceptual research concerning "meaningful work" (Ciulla 2000), which looks into, for example, how certain features of job design, performance and outcomes help satisfy a worker's needs and deepest longings. Nonetheless, it is this intrinsic social dimension of work (Pontifical Council for Justice and Peace (2005), Compendium of the Social Doctrine of the Church, henceforth, 
CSDC 273) that allows it to be a locus of meaning which human beings can share. Meaning is a feature of work as a form of praxis.

Let us now explore the differences between making (poiesis) and doing (praxis) further. For Aristotle, examples of "making” would be the crafts and the fine arts (NE 1174a). What is important in these cases is the external object itself, as a work of art or craft, with the skill of the artist or artisan only coming in second. On the contrary, if the activity centers on the subjective result, such as when Athenian gentlemen engage in joint deliberation and action to achieve eudaimonia or flourishing, we call it “doing”. It is an immanent or reflexive activity, originating from the agent and ending in the agent himself, not in an external object. In doing, the human being is both the agent and patient, the origin and result of production. Doing, therefore, is a process of "selfproduction", where man becomes maker (homo faber) of himself, because of the new characteristics, skills or virtues acquired. The main result of "doing” is not an artifact, but an operative habit or virtue that the doer acquires. And in acquiring virtues or good habits, "self-production" becomes at the same time a form of "self-perfection". While "making" is guided by skills of craftsmanship or the fine arts, "doing" is guided by the virtue of prudence, practical reasoning or practical wisdom.

Making and doing are inseparable dimensions in any form of work. In principle, one could put a greater emphasis on the external result (making) than on the internal (doing). For Aristotle, this is the case of the productive class. Not being citizens, the members of the productive class participate very limitedly in the political common good or eudaimonia. This, however, would be inconsistent with Catholic Social Teaching (CST), which grants primacy to the internal or subjective dimension of work over the 
external or objective dimension (Laborem exercens 6, CSDC 270-271). For Aristotle, this condition of prioritizing the internal or subjective aspect of work over the external or objective is a prerogative only for the elite, for citizens engaged in leisure, democratic deliberation and contemplation. For CST, however, work is not a mere commodity or factor of production, but a means for self-perfection available to everyone. This is because human beings are always more important than the things they produce. And although in their work, they also develop craftsmanship and the fine arts, these outcomes are secondary to the moral virtues acquired. Whereas for Aristotle, therefore, work belongs to the realm of poiesis or making, for Aquinas and CST, the conceptualization of work changes such that it is assimilated into a form of praxis or doing.

Finally, for a firm to fulfil its common good, the goods and services produced must be truly useful and satisfy the legitimate needs and wants of people ("real goods”). On this account, not only pornography and drugs, but also pet rocks, for instance, ought to be disqualified (“apparent goods"). Production must also make the best use of scarce resources and be efficient.. Only when these conditions are observed would businesses comply with their social function of contributing to the wider common good, by observing economic discipline and upholding values (CSDC 338).

To recapitulate, the common good of the firm is the work in common that allows human beings not only to produce goods and services (the objective dimension), but more importantly, to develop technical or artistic skills and intellectual and moral virtues (the subjective dimension). In business, entrepreneurial initiative, creativity and cooperation deserve special mention among the virtues (CSDC 336). Entrepreneurial 
initiative is not just waiting for things to happen, but taking the lead in identifying a genuine human need and seeking to remedy it. Creativity means, above all, exercising one's mental capacities in proposing solutions that are novel and unique, apart from being effective. Cooperativeness indicates the ability to work with others toward a common goal that cannot be reached individually. These are goods internal to particular practices found in business institutions.

\section{Corporate Citizens and their Participation in the Corporate Common Good}

\section{Beyond the metaphor of corporate citizenship}

Business theory has borrowed the notion of citizenship from politics for several reasons. Above all, to highlight the social dimension of firms, and secondly, to analyze the role of power in resolving conflicts. Through the concept of citizenship, politics also lends to firms a sense of identity, by way of membership in the community, and a justification for their rights and responsibilities as legal persons. Wood and associates even go as far as affirming that business organizations, in comparison to individual persons, are "secondary citizens" (Wood et al. 2006: 35-6). Although we normally treat business organizations as independent legal entities carrying out their activities in pursuit of particular goals, they only exist thanks to the objectives and the resources furnished by their incorporators. Corporations are collective instruments created by individual citizens to achieve ends which they, otherwise, won't be able to reach effectively. Those ends are likely to have a sociopolitical dimension and reflect the values of the community. 
But the notion of citizenship itself has a long history. To discover its potential in clarifying the status of corporations and the issues concerning how they ought to be governed, it would be convenient to have a look into the origins and evolution of this concept.

In the Politics, Aristotle delves into the question of citizenship observing that the "state is composite, [and] like any other whole [is] made up of many parts — these are the citizens, who compose it” (Pltcs 1274b). He then proceeds to identify who the citizen is, and the meaning of the term, by determining what the citizen does. Next, Aristotle differentiates citizens from other classes of people in the state, explaining the process by which one acquires citizenship. Finally, he distinguishes the various kinds of citizens depending on the form of government adopted by the state. Only within this context could the query "what makes a citizen a good citizen?” receive an appropriate response.

According to Aristotle, "a citizen in the strictest sense, against whom no such exception can be taken" is he who "shares in the administration of justice, and in offices” (Pltcs 1275a). The essential task of the citizen is to participate in deciding what is good and just in the state and carrying this out. A citizen is a "juryman and member of the assembly", to whom "is reserved the right of deliberating or judging about some things or about all things” (Pltcs 1275b). Although many people in a state may actually participate in deliberating and deciding on the public good, only citizens possess this right. What characterizes a citizen is "the power to take part in the deliberative or judicial administration of any state" (Pltcs 1275b). This does not mean that a citizen 
always has to hold office. It would suffice that he have the power to occupy such a post, "sharing in governing and being governed" (Pltcs 1283b).

Aristotle was aware that the state needed other kinds of people aside from citizens in order to be viable (Pltcs 1278a). Mere necessity for the state's survival or flourishing did not automatically qualify one for citizenship. Consider children who, not being grown-up, cannot exercise deliberation and judgment. They may only be called citizens on certain assumptions. Neither are the members of the artisan class citizens. In ancient times, the artisan class was composed by slaves and foreigners: "The necessary people are either slaves who minister to the wants of individuals, or mechanics and laborers who are servants of the community” (Pltcs 1278a). Citizens do not even refer to free men as such — in which case foreign workers would be citizens — but only to free men who are exempted from providing menial services. Citizenship requires distance from the tyranny of having to satisfy daily needs. Participating in the discussion about the public good demands leisure. Because of this, citizenship implies relative affluence; it is not something everyone can afford.

Aristotle enumerates the different classes that constitute the state and are needed for its existence: the food-producing class or farmers, artisans, traders, laborers, the military and so forth (Pltcs 1291a). Nonetheless, "as the soul may be said to be more truly part of an animal than the body, so the higher parts of the states, that is to say, the warrior class, the class engaged in the administration of justice, and that engaged in deliberation, which is the special business of political understanding - these are more essential to the state than the parts which minister to the necessaries of life" (Pltcs 1291a). To the extent citizens are involved in deciding the public good, they are like the 
soul, the most important part of the state, although by themselves they do not suffice to constitute the state.

Not all residents of a state are citizens. Resident aliens and slaves share with citizens the same living space, although not the rights (Pltcs 1274a). To be a citizen, it is not enough to have the right to sue or be sued before a state's tribunals; this could also be obtained by resident aliens through treaties between states. Citizens have more and farther-reaching rights. Insofar as resident aliens are normally obliged to have a citizenpatron, they could only participate in the community very imperfectly, never in their own name and always under the citizen-patron's tutelage. In this respect, they are much like children, the old and the feeble.

How does one become a citizen? Excluding cases where one becomes a citizen accidentally, "in practice a citizen is defined to be one of whom both the parents are citizens" (Pltcs 1275b), Aristotle responds. To become a citizen it is not sufficient to reside in a particular state nor to enjoy some rights; one would also have to be an adult possessing adequate wealth, and be the offspring of people who are citizens. Citizens are the only ones qualified to rule or govern the state.

Having defined citizenship and established the process by which it is acquired, Aristotle insists that there are as many kinds of citizenship as states or forms of government, "he who is a citizen in democracy will often not be a citizen in an oligarchy” (Pltcs 1275a). Since citizens differ according to forms of government, his definition is best suited to a democracy. It does not apply, to states where people - the demes — are not acknowledged, do not hold regular assemblies, nor decide on law-suits 
(Pltcs 1275b). Neither does it apply to aristocracies, where citizenship is based on excellence and merit, nor in oligarchies, where it is based on wealth (Pltcs 1278a).

Even allowing for variances in citizenship, Aristotle nonetheless affirms that ideally the excellence of the good citizen coincides with the excellence of the good man. That occurs in the best of states, so long as the good man and citizen takes part in public affairs (Pltcs 1278b) in a manner consonant with the individual and social nature of the human being.

Twenty four centuries later, several models and typologies of citizenship —still based on the kinds of states — have been offered (Stokes 2002; Crane and Matten 2004; Wood et al. 2006). These categories could be collapsed into two, with their respective variants: liberal-minimalist citizenship, on the one hand, and civic republican or communitarian citizenship, on the other.

The liberal-minimalist ideal conceives citizenship fundamentally as freedom from oppression and protection against the arbitrary rule of absolutist government (Crane, Matten and Moon 2003: 7-9). Citizens are vested with political rights to choose their rulers, to vote and to be voted into public office. The duty of government is to secure these individual political rights with a few others which form the core of citizenship. For some, this minimum is composed of the rights to life, to liberty and to property (Locke); for others, the right to a just share of the social product or utility (Smith, Bentham); while for still others, the rights to equality before the law and to free rational agency or autonomy (Kant). What is important is that this minimum of rights and freedoms be guaranteed. With some latitude we can include in this group the 
libertarians (Wood et al. 2006: 41-42, 44), who support a very limited state, and those who uphold a deliberative democracy (Crane, Matten and Moon 2003: 15-16), who want a more robust form of government to safeguard conditions of equality in political discourse.

Civic republican or communitarian citizenship emphasizes participation in the public good by fostering community ties and the practice of civic virtues (Crane, Matten and Moon 2003: 9; Wood et al 2006: 42-43). While liberal-minimalist citizenship is marked by "negative freedoms" or "freedoms from" state oppression and interference, civic republican or communitarian citizenship is characterized by "positive freedoms" or "freedoms to" actively seek the common good. Liberal-minimalist citizenship stresses individual rights or state-guaranteed powers against collective pressure; civic republican or communitarian citizenship underscores belonging to the group as the factor constitutive of identity and that lends meaning. It is the group with its hierarchically ordered set of goods, rules and practices that makes virtue or human excellence possible.

Within the civic republican or communitarian mindset, the role of government is to strengthen institutions such as families, neighborhoods, schools, churches and so forth. Only when these institutions are lacking should government intervene, but without losing sight of its subsidiary function. Similarly, state coercive power should be used so that evil is minimized, sanctioned and punished. There is greater insistence on fulfilling obligations — to protect the family, obey the law, pay taxes and comply with jury or military service, and so forth — than on demanding rights, which separate the individual from the group. Developmental democracy (J.S. Mill) may be said to favor 
civic republican or communitarian citizenship in the understanding that ties and obligations link one more to civil society than to government (Crane, Matten and Moon 2003: 14-15).

Liberal-minimalist citizenship guarantees the right to stand up to the group; civic republican or communitarian citizenship admonishes one to participate in social affairs and contribute to the common good. Liberal-minimalist citizenship is limited with regard to rights; civic republican or communitarian citizenship, maximalist in terms of duties. Insofar as Aristotle accentuates the embeddedness of citizenship in a sociocultural and historical context, as well as the mutual dependence between the human excellence of the citizen and the excellence of polis, he unequivocally sides with the civic republican or communitarian model.

How do these different views of citizenship measure up with the notion of the corporation as a citizen, as a “corporate citizen”? As a citizen in the liberal-minimalist mold, a corporation would be expected, first and foremost, to protect its "right to exist", based on the freedom of association of its incorporators, and its "license to operate", resting on the freedom of enterprise. A corporation would very much prefer "to stick to its own business”, embarking on philanthropic activities only with utmost reluctance. In such instances, corporations could justify their behavior in line with "enlightened selfinterest”; that is, corporate philanthropy is all right because it ultimately benefits the bottom line, it's just an additional “cost of doing business”. In other social and political issues, the corporation as liberal-minimalist citizen would be quite passive. This description of liberal-minimalist corporate citizenship would correspond to a mix of what other authors call limited and equivalent views of corporate citizenship (Crane and 
Matten 2004: 63-67). Similarly, it would have great affinity with a shareholder view of the firm focused exclusively in increasing value.

On the other hand, if a corporation were to follow the civic republican or communitarian type of citizenship, apart from exercising political, civil and social rights, it would also strive to fulfil political, civil and social obligations. Such a company would not hesitate to step in, harnessing resources and expertise, when government is remiss. It could provide social rights (e.g. healthcare or housing), enable civil rights (e.g. be an "equal opportunity employer") and serve as a channel for the exercise of political rights (e.g. host a forum for political debate on certain issues). This sort of company justifies sociopolitical action, because it thinks that its mission transcends purely economic goals. Community involvement and political activism characterize the civic republican or communitarian corporate citizen. Responsibility is not only of an economic nature, but sociopolitical as well; and it is owed not only to shareholders, but to other stakeholder groups also. A company of this type falls within the extended view of corporate citizenship (Crane and Matten 2004: 67-70).

\section{Citizens of the corporate polity}

There is another possible interpretation of corporate citizenship, different from the understanding of the corporation itself as a citizen of the state. It consists in the view of the corporation as an analogue of the state and of the various stakeholder groups as potential citizens. The approach and intent is similar to that carried out by Manville and Ober (2003) who tried to draw management lessons from classical Athenian democracy. Here we shall try to examine the different stakeholder groups and decide which of them 
best fits into the general definition of citizenship. Thus we will find out who among the different stakeholders should primarily be entrusted with governance.

Drawing from Wood's different approaches to corporate citizenship, we may link the liberal-minimalist perspective of citizenship to a notion of the corporation as a "civic association" and the civic republican or communitarian view to an idea of the firm as a corporate polity (Wood et al. 2006: 41-45). The liberal-minimalist theory of citizenship insists on individual freedom — dressed in the form of rights - to pursue self-interests. But the satisfaction of self-interests, insofar as divergent or rivalrous, cannot constitute a corporate common good. The corporation is then reduced to a "civic association", some sort of "clearing house" where minimum restraints are applied to keep an individual from infringing on the rights of another. The different groups of people dealing with the corporation do not really behave as "citizens" but mere “residents of a common jurisdiction". They comply with the laws, but only as a means to reach individual goals. Coercive laws are the only forces that keep them together. There is no attachment or loyalty among themselves nor between them and the corporation. Relationships are purely contractual, and the corporation is nothing more than a "nexus of contracts". Shareholder-principals who provide capital are granted ownership rights and manager-agents are hired in the understanding that they will maximize the former's investment returns. The corporation is an empty shell wherein investment, employment and sales contracts are negotiated and fulfilled: “The language of citizenship might even be used, but the motivation is not to provide a collective good or to contribute to society's [or we may say in this case, the corporation's] well being, but only to achieve a private end” (Wood et al. 2006: 42). 
The demands of a civic republican or communitarian kind of citizenship on the stakeholders of the corporate polity will be altogether different. Since their personal flourishing is not independent from that of the corporate polity, they would actively participate in the deliberation and execution of the corporate good. This does not mean disregard for individual rights; it simply means that those rights are neither supreme nor absolute goods. The recognition, enforcement and respect for those individual rights should always be done within the context of the corporate common good. This common good is not inimical to individual goods such as rights. What is needed is an order or hierarchy, such that "goods in respect of another" — for instance, rights — are subjected to "goods in themselves", and the various "goods in themselves" subjected in turn to the "common good" of the corporate polity. For instance, the right to free enterprise would not include the right to buy and sell body parts, if only to safeguard the physical integrity of prospective suppliers.

A misconstrual of the common good may be at the root of the conflict that Wood detects between communitarian and global citizenships (Wood et al 2006: 42-46). She claims that attachment to the local community may be at odds with a relationship with a multicultural global society. But global society and local community do not exist on the same level. To be sure, serious conflicts among these different levels of organization may arise. However, the strength and success of the superior levels in terms of human flourishing depends on that of the inferior levels and vice versa, as the principles of subsidiarity and solidarity explain.

Let us clarify this relationship further by means of an example. A corporation that applies pollution control measures in its home community but neglects them in 
other communities where it is a mere guest is simply not a good corporate citizen. It need not follow a free-standing "universalist" standard of global citizenship to recognize its duty to reduce pollution wherever it holds operations; it would be sufficient to become aware of the interdependence between its home and host environments, between its efforts to curb pollution locally and globally. Only by identifying itself with the good of its home region - that is, by subscribing to the communitarian ideal of citizenship — can a corporation realistically contribute to the good of a wider global and multicultural society.

To our knowledge, the analysis of the different stakeholder groups as prospective citizens of the corporate polity has only been carried out from the viewpoint of liberal-minimalist citizenship (Crane and Matten 2004). In the succeeding pages, we shall draw a picture of the various stakeholders that comes closer to the civic republican or communitarian ideal: Who among the different stakeholders best fulfills the requirements of the civic republican or communitarian citizenship within the corporate polity? Who among them is most deserving to govern?

Consonant with the civic republican or communitarian model, for Aristotle, a citizen is he who "shares in the administration of justice, and in offices" (Pltcs 1275a). By "administration of justice" he means taking part in the deliberative or judicial administration of the state (Pltcs 1275b), and by "sharing in offices”, holding some kind of rule (Pltcs 1276a). In substance, "a citizen is one who shares in governing and being governed” (Pltcs 1283b). 
If citizenship consists in participating in government, who is best equipped to do so in the firm as a corporate polity? Shareholders are the first to come to mind. Having provided financial capital, they are normally acknowledged as the "owners" of the company. And in accordance with the application of agency theory to business firms, laws are generally designed to protect their interests as "principals" against possible abuse by “manager-agents”.

Yet this account is not entirely accurate. The shareholders' only real property is a piece of paper, the certificate that entitles them to a "share" of the firm's residual equity. Depending on whether the company has been profitable, they may receive dividends or sell shares at a higher price. But none of these can be guaranteed. Other shareholder rights include choosing board members, participating in general meetings and voting on proposed changes in capital structure. Nothing more, substantially. It would be erroneous to consider shareholders as the real "owners" of a company, when all they own are share certificates (Clarkson and Deck 1998: 608). What's more, given the huge number of shareholders, their fragmented interests and dependence on management, it is quite understandable that they don't consider themselves “owners” at all. Nor do they act as such.

Contrary to general opinion, shareholders do not “own” the company. They just cannot walk into the company premises and occupy a room or start selling the furniture, for example. They hold the right to a share of its residual equity, and consequently, the right to vote in shareholders' meetings. Of course they could also always sell their shares for whatever reason. The problem is that shareholders hardly exercise their rights, and this for various motives. 
In public companies, shareholders form such a huge and diverse group with interminably splintered interests. It's easy to imagine why a shareholder, with an infinitesimal holding, would not bother to attend general shareholder meetings; his vote won't make a difference. That's something for institutional shareholders, major shareholders, and above all, management to worry about. For his part, the "regular Joe" shareholder doesn't hold on to his shares very long and sells as soon as he thinks he'll make a reasonable profit. Beyond this, he feels no further commitment to the firm.

Because of their rights to residual equity, shareholders may claim liberalminimalist citizenship within the corporate polity. But that is not sufficient for a civic republican or communitarian kind of citizenship, which requires the exercise of rights with a view to the corporate common good.

We should then broaden the field to include other stakeholders in our quest for civic republican or communitarian citizens of the corporate polity. "Stakeholders" are defined as all those who may have "legitimate interests" (Donaldson and Preston 1995: 67) in the firm. This doesn’t mean, however, that every one of those interests warrants formal legal protection. The legitimacy of stakeholder interests could come, not from courts, but from social recognition. As for the requirement of active involvement in governance, we should not interpret it in the sense that all stakeholders have to participate in all corporate decisions. It would be enough that those with legitimate interests intervene in the issues that concern them. 
The next stakeholder group we shall turn to is that of clients or consumers. They have always been a pampered lot. In recent decades, corporate strategy has often been formulated from their perspective, to satisfy their needs and serve them better, coming up with the best “value proposition” (Porter 1980): “The customer is always right” or “The customer is king”. "Consumer sovereignty”, however, has been better known in the breach than in the observance.

Until recently, the market mindset was based on the principle "caveat emptor" or “buyer beware” (Boatright 2000: 273). Responsibility for the consumer's interest lay almost exclusively with the consumer himself. The consumer right consists in not buying a product, if he disagrees with the terms and conditions. Nowadays, especially in the developed world, we've seen a vast expansion of consumer rights. Aside from the right to free market choices, we also enjoy — in varying degrees — the right to fair market prices, to safe and efficacious products, to truthful advertising and honest communications, to privacy and so forth (Crane and Matten 2004: 270). Moreover, tests have been designed to protect "consumer sovereignty" in its different dimensions: from consumer capability (freedom from limitations in rational decision-making) to information (availability of relevant data) and to choice (switching possibility) (Crane and Matten 2004: 289). For example, by virtue of the first aspect of consumer sovereignty, neither tobacco nor alcohol should be sold to minors; by virtue of the second, foodstuffs should be properly labelled for common allergens; and by virtue of the third, we should be able to change our telephone service providers while keeping our numbers. The guarantee of these rights in support of consumer sovereignty could be said to justify a liberal-minimalist corporate citizenship for clients and consumers. 
How do consumers as liberal-minimalist corporate citizens make the transition to civic republican or communitarian ones? They would in the measure that they somehow participate in the governance of the corporation. For instance, when consumers decide to patronize and recommend - or on the contrary, boycott- a company, because of ethical, social and environmental reasons. Consumers could also flex their "governance" muscle by participating in product design and promotion; take for granted, when passengers share travel preferences with the airlines whose frequent flier programs they have joined. These consumers could be called civic republican or communitarian corporate citizens. But the issue would then be: How effective are they in influencing corporate policy? That would be the ultimate test of civic republican or communitarian corporate citizenship for consumers.

The turn now comes for competitors and suppliers. How do they qualify as citizens of the corporate polity? Firstly, in market economies, the reciprocal rights of competitors and suppliers — the "right to fair play" — are laid down in competition law. These would include the freedom to enter and to leave the market, the right to set prices without coercion, the right to offer products to potential customers, and so forth (Crane and Matten 2004: 305). Upholding these rights may suffice for liberal-minimalist corporate citizenship. But corporate citizenship of a civic republican or communitarian kind would again demand a higher level of engagement.

For example, suppliers could organize themselves around an ethical supply chain management initiative, such that unfair labor practices (child labor), unhealthy working conditions (sweatshops) and environmental degradation are greatly diminished if not eliminated. They could do this even before Third World governments —often hampered 
by limited resources and corruption — introduce their own legislations. Also, suppliers and competitors could engage in "fair trade" agreements like those in coffee, tea and cocoa; they could guarantee minimum prices and offer better conditions to small commodity growers in developing countries (Crane and Matten 2004: 333). These activities would push suppliers and competitors up the ranks to civic republican or communitarian grade corporate citizenship. Yet unfortunately, these practices are still uncommon and their effects on corporate governance quite unknown.

The government's role as a stakeholder of the corporation is affected by a serious ambivalence (Crane and Matten 2004: 391). On the one hand, it seems more proper to think of the corporation as a stakeholder of the state. In modern liberal democracies, governments are formed by representatives of the citizenry, and indirectly, of the different intermediate associations and civil society organizations. On the other hand, the state could also constitute a stakeholder group; not only by owning a significant, if not a controlling tranche of shares, but in other ways as well.

With their monopoly on force, governments could choose either to restrict or enable corporate activity. States somehow restrict business activity by collecting taxes — which eat into the profits or represent a considerable cost—; but they also enable business by allowing tax breaks or granting subsidies. Meanwhile, we could see states as either depending on or competing with corporations. Governments could compete with multinational companies in providing welfare and even security, for example, in developing countries. Yet were it not for independent business organizations, borne from the freedom of enterprise and association of citizens, states would be paralyzed or become terribly inefficient, as in communist countries. 
As corporate stakeholders, states undoubtedly hold important rights —enough to qualify them as a liberal-minimalist corporate citizen-. Remember that corporations only exist thanks to a legal charter, that is, an explicit recognition by the state. There is no escaping government influence, both for good and for ill. The problem arises when we try to apply the civic republican or communitarian standard. What is the desirable level of state involvement in corporate governance?

The most we could venture is to say that it lies on a golden mean. Not statism, where private initiative, freedom of association and freedom of enterprise have all been annihilated and the state has completely taken over the economy. But neither absolute laissez faire, where markets would have usurped functions such as internal and external security or the administration of justice, effectively getting rid of the state. Apart from the degree of involvement, there are certain matters or issues that should be of one or the other's competence. Government should not be in the business of developing and peddling software, for example, no less than corporations setting up private tribunals of justice or private armies. The state could behave as a good civic republican or communitarian corporate citizen if it proceeds in accordance with the principle of subsidiarity in relation with corporations, promoting privatization and self-regulation without renouncing to its areas of competence.

Only the stakeholder group composed of a company's workers or employees, including management remains. Among the different stakeholders, employees are the ones most closely integrated and identified with the corporation: “employees, in many cases even physically 'constitute' the corporation. They are perhaps the most important 
production factor or 'resource' of the corporation, they represent the company towards most other stakeholders, and act in the name of the corporation towards them" (Crane and Matten 2004: 224).

A liberal-minimalist analysis of employees as corporate citizens would limit itself to their rights and duties in the employment contract: a right to fair wages, a right to healthy and safe working conditions, freedom from unjust discrimination, a duty to provide an acceptable level of work performance and quality, a duty to respect company property, and so forth (Crane and Matten 2004: 228). The civic republican or communitarian standard would look into other areas, such as the economic externalities and the socioethical opportunities that escape those contracts. No employment contract could fully capture the demands of employee loyalty, and its breaches would hardly be actionable in the courts. Yet employee loyalty counts as an enormous positive externality for the company and an opportunity for growth in virtue for the employee. Employee loyalty also makes demands on the company. A company should never consider the employee merely as an expendable resource, the first one to jettison when the sailing gets rough. Instead, the corporation should try to reciprocate employee loyalty by apportioning resources and allowing for continuing professional development. Loyalty is not so much the result of locking-in assets as a mutual concern for each other's flourishing and well-being.

Among employees, those who own shares in the company, particularly, shareholding-managers merit special consideration. Let us recall for an instant Aristotle's teaching that citizens carry out the task of government for no one else but themselves: they govern their own affairs, they practice self-governance. This means 
that no matter how involved one may be in government, if he did so for the benefit of others but himself — think of someone called upon to rule in a foreign land, for instance - that doesn't turn him into a citizen of that land, since citizenship requires self-rule. At most, he could be something like a “professional governor". That's the difference between a simple manager and a shareholding-manager. In some measure, the demand for self-rule could also resolve agency problems, since the shareholding employee —and especially the shareholding manager — now becomes both agent and principal at once. By owning shares through stock option plans, managers begin to exercise power and authority over the firm in their own name, as principals, albeit collectively.

That manager and shareholder, agent and principal, governor and governed coincide is precisely the biggest advantage of workers over other stakeholder groups. Only here can the condition of actively taking part in corporate self-government be adequately fulfilled. Only here, too, can we find the objective dimension of work - that is, the external goods and services produced— united to its subjective dimension — that is, the improvements in knowledge, skills, habits and virtues that work causes in the worker- Alienation from the worker of the products of his labor is avoided. In this sense, cooperatives, or business organizations that are run and controlled by their owners, would fit the definition of a self-governing corporate polity to perfection. Its shareholding workers and managers would represent civic republican or communitarian corporate citizenship in the highest form.

For this reason, other non-shareholding employees have to be set apart. Surely the corporation cannot exist without them, yet they shouldn't be considered corporate 
citizens because their tasks are carried out for others - that is, the shareholders - and not for themselves. The situation of non-shareholding employees is very similar to that of the artisan class composed of slaves and foreigners in the Greek city-states (Pltcs 1278a). Without them, the city-state would not stand; yet their integration in the citystate was very limited and their participation in government practically nill. Similarly, the other stakeholder groups — shareholders, clients, consumers, competitors, suppliers, governments, states and non-shareholding workers - through contracts and agreements hold a status comparable to those who enjoyed certain rights in the Greek city-states where they resided, due to trade treaties or military alliances, without being citizens (Pltcs 1274b). Possessing some rights is not enough, participation in government is necessary, as a liberal-minimalist model of citizenship would require. But neither is the mere possession of rights sufficient, they have to be exercised, to qualify for civic republican or communitarian citizenship, be it political or corporate.

\section{The Quest for Personal and Corporate Virtues}

Through work, a firm's members take part in the different goods, both material (products, profits) and immaterial (virtues, skills, meaning), that their joint effort creates. This participation through work is both a duty and a right for a firm's members. It is a duty because every human being is expected to contribute to the economic, cultural, political and social life (CSDC 189); and a right because work enables human beings to share not only in profits, but also in management and ownership (CSDC 281). Thus workers are able to employ and develop, besides their physical strength, their mental faculties as well. Full participation in the material and immaterial goods that a firm produces is, of course, more of a goal or objective than a reality oftentimes. 
Participation in the common good of the firm —of which profits form part- is not limited to shareholders, as the financial theory of the firm suggests (Friedman 1970), but also extends to other stakeholders (Freeman 1984). Shareholders participate because their financial resources, representing capitalized work, are used by the firm. In the preceding section we have just traced the participation of each stakeholder group through work: employees, customers, suppliers, competitors and so forth. There is a hierarchy, however, to be observed among stakeholders: persons take precedence over non-persons such as the environment, and direct stakeholders over indirect stakeholders. This is in consonance with the principle that work be considered a form of praxis, where the subjective dimension precedes the objective dimension. From the perspective of participation, management workers who also own equity stakes are probably the best positioned to contribute, achieve and benefit from the common good of the firm. Because of equity ownership, they participate in the financial resources the firm needs, because of their work, they participate in the production process, and because of their specific management roles, they participate in organizational governance. The need for participation in corporate governance is a consequence of the fact that the common good is not an abstract, Platonic idea to be contemplated by some autocratic visionary. Instead, it is a practical matter to be decided on by a firm's members through joint deliberation or dialogue.

Nonetheless, effective participation in the common good of the firm is never automatic. It requires the virtue of justice, in its distributive and contributive forms. Distributive justice refers to the duties and obligations of the whole (the firm) to its parts (workers and other stakeholders), while contributive justice, the duties and 
obligations of the parts to the whole. For example, distributive justice demands paying a just wage -in CST, a "living wage", that takes into account not only the individual worker's needs, but those of his dependents as well- while contributive justice requires that workers dedicate their best efforts to production, taking care of the firm's resources at the same time. Duties and obligations always have corresponding rights; so the enjoyment of certain rights entails the fulfilment of duties and obligations. Yet to conceive the welter of relationships in the firm exclusively in terms of rights and duties would lead to an impoverished outlook. For justice, law and rights only prescribe minimums, not the excellence or perfection at which virtue aims.

Recently, Hsieh has advocated certain institutional reforms in the modern production system to better align it with the demands of liberal egalitarian or Rawlsian justice (Hsieh 2008). Among them are the guarantees for meaningful work at the individual worker level, worker participation in the governance of firms at the organizational level and democratic participation in the control of the means of production at the societal level. Despite the divergence in backgrounds, Rawlsian versus Aristotelian-Thomistic, the coincidence at least in the letter of our proposals is quite remarkable indeed. We both agree in the importance of participation in itself, at work and in institutions, almost independently of its impact on productive efficiency, which is, perhaps, the only justification acceptable to modern industrial capitalism. Hsieh grounds this on the liberal egalitarian ideal of distributive justice, while we base our claim on the Aristotelian-Thomistic notion of the common good, which includes, but is not limited to distributive justice alone, as indicated above. Legal justice is equally important. 
How can participatory work as the common good of the firm help in acquiring and developing the virtues? We should first of all clarify what the virtues are, since they are often cast in misleading terms when differentiated from the objects of other major ethical schools. According to this conventional account, virtue ethics emphasizes the character traits of the actor or agent, while deontological ethics focuses on the act itself and utilitarian ethics, on the results or outcomes. As Koehn has reminded us, both the act and its outcomes are as important as the character of the agent himself, since this develops precisely from the performance of certain actions as its most significant -albeit internal- result (Koehn 1995: 533-4). What's more, no true description of a virtuous act can be given without looking into the thought processes, intention and desire, the practical reasoning somehow manifested in the character of the agent, acting within particular circumstances and bringing about certain consequences. Hartman expresses this same thought when he strongly argues against the entrenched dichotomy between the normative and the empirical or descriptive, also known as the "separation thesis", in ethics and decision making in general (Hartman 2008).

There are several points of agreement among Aristotelian business ethicists in their characterization of the virtues. Virtues speak of "excellences", of doing what is best for human beings (Solomon 1992: 327) and seeking what is outstanding in friendly competition (Koehn 1995: 537). Virtues also point to right practical judgment or phronesis, which includes right perception and deliberation, and sensitiveness to the particulars of one's identity, roles and situation (Solomon 1992: 327-329). This feature may also be explained as a habitual conformity between right thinking and right desire ultimately shown in practical reasoning (Koehn 1995: 536) or the harmony among rationality, emotions and intuitions in decisions and actions (Hartman 2008: 257). A 
third trait refers to an integrity or wholeness in one's life, such that one's practices, roles, duties and responsibilities seamlessly come together (Solomon 1992: 328-329) and a continuity or identity is preserved between one's past and future (Koehn 1995: 536; Hartman 2006: 72).

All of these dimensions of the virtues may be enhanced (or hindered) by the participatory work carried out in the firm. As Solomon (1992: 335) remarks, since business is above all a social activity involving other people, Aristotelian virtues are also business virtues. Moreover, "while business life has its specific goals and distinctive practices and people in business have their particular concerns, loyalties, roles and responsibilities, there is no 'business world' apart from the people who work in business and the integrity of those people determines the integrity of the organization as well as vice versa” (Solomon 1992: 338). Moore, for his part, has identified various components of a virtuous "corporate character", some "major”, such as the sustenance of a practice and the pursuit of its corresponding excellence, and some "minor", such as a "power-balanced structure" and the implementation of systems and processes that fight bias and encourage questioning (Moore 2005: 676). And lastly, for Hartman, “corporate culture, as well as structures and systems, can be deployed to encourage and accommodate good character” (Hartman 2006: 72). He particularly advocates a careful choice in the firm one works for, given the occurrence of a form of "adaptive preference formation": although the right corporate culture may not be a sufficient condition for personal virtue, nonetheless it surely is a necessary one (Hartman 2006: 79).

Ensuring the prevalence of internal goods or the subjective dimension of work over external goods or the objective dimension is also for Moore -in his MacIntyrean 
interpretation of Aristotle- the "fundamental challenge" that corporations face in avoiding “corruption” (Moore 2005: 661). Following MacIntyre (1985: 188-189), Moore speaks of "goods internal to practice", "internal goods" or "goods of excellence" as equivalents of what we call in CST the "subjective dimension or result" of work, and of "goods external to practice”, “external goods" or "goods of effectiveness" as corresponding to the "objective dimension or result" of work. Moore (2005: 660) cites as examples of "internal goods" those that are "generally derivable from the exercise of the virtues in search for excellence within the context of a particular practice”, such as loving relationships, playing or listening to music or intellectual stimulation, and of “external goods”, “prestige, status or money, which can be achieved in a variety of alternative ways not linked to any particular practice”. Similarly, for "practices”, Moore takes MacIntyre’s definition, as “any coherent and complex form of socially established cooperative human activity" (MacIntyre 1985: 187), and for “institutions”, some form of human community that houses practices and are "characteristically and necessarily concerned with [...] external goods” (MacIntyre 1985: 194). Therefore, work (e.g., the retailing function), especially if considered from its subjective angle (praxis or doing), would be some sort of "practice", and the firm or business corporation, a kind of “institution”. On MacIntyre’s -and Moore’s- understanding, however, institutions are necessarily corrupt and corrupting of practices, insofar as they subvert the proper order of goods, giving precedence to external goods of effectiveness over internal goods of excellence. In other words, institutions tend to view work from its objective angle (poiesis or making), focusing on external goods. Although intended as a criticism particularly of modern industrial or capitalist business organizations, a broader applicability is generally implied. 
We disagree with MacIntyre and Moore regarding the inherently corrupt and corrupting nature of institutions in general and of firms in particular. At least, we have found no basis for adopting such a stand in our reading of Aristotle's Politics as developed in the previous sections, and much less in the texts from Aquinas and CST. It would be difficult to hold simultaneously, on the one hand, that human beings, because of their social nature, necessarily belong and live in institutions, and on the other, that these institutions are always corrupt. Moreover, as MacIntyre and Moore themselves take pains in affirming, there are no practices without institutions nor institutions without practices. Therefore, if institutions were necessarily corrupt, to some extent, it would not even be possible for there to be practices since, also by MacIntyre and Moore's definition, these always seem to be "virtuous", that is, they put internal goods of excellence before external goods of effectiveness.

Once this crucial difference with MacIntyre and Moore regarding the ethical neutrality of both practices (work) and institutions (firms) has been acknowledged, we find no further trouble in agreeing with Moore's proposal on how the "virtuous corporation" could come about. A "virtuous corporation", one that has achieved its common good, could be characterized in several ways. In it the internal goods, such as "the enjoyment of the exercise of practical skills, the stimulation that the competitive situation affords, pride in accomplishment and the personal dignity that derives from a job well done” (Moore 2005: 660) prevail over the pursuit of external goods, such as profits or reputation. This is, of course, the outcome of a constant struggle in which all the members of the firm, but especially those in positions of authority and power, cannot afford to let their guard down. In another account, we could say that a "virtuous corporation” is one that has reached and maintained that delicate balance between 
internal and external goods. This equilibrium requires a sufficient amount of external goods which, after all, are also genuinely goods, to allow the firm as a whole and its individual members to rightly pursue and advance in the internal goods. The mutually sustaining or reinforcing character of both types of goods should not be overlooked. And a third one is by suggesting that, in the "excellent corporation", the virtues are practiced not only at the personal level, but also, and jointly, as in a biconditional relation, at the institutional or firm level, in terms of "corporate character" (Moore 2005: 663-4). Personal virtues facilitate institutional or corporate virtues in the same way that institutional or corporate virtues facilitate personal virtues. Participatory work affords one with a privileged opportunity to seek excellence, exercise practical judgment and strengthen integrity together with others.

Work, therefore, is not only an opportunity to avoid idleness and subsequent vices, as it is cast by most pre-modern manuals of moral theology. Neither is it just a condition that allows one to practice the cardinal and theological virtues later or in other life spheres, as Alford and Naughton (2001: 215-222) seem to imply. All the virtues can and should be lived in and through work itself. If work is truly well done, it becomes an occasion for contemplation, which is in some sense the highest of all virtues. For Aquinas and CST, this entails doing one's work ultimately for love of God. This is Aquinas and CST's response to that longing which Aristotle so pointedly formulated in his ethics.

\section{Conclusion}


The common good acts as an integrative force on several different levels. We have defined the common good of the firm as the participatory work in which all its different members engage, insofar as this provides them firstly, with an opportunity to acquire and develop skills, virtues and meaning (subjective dimension), and secondly, with a chance to efficiently or profitably produce goods and services that society needs (objective dimension). This is what unites the various stakeholders in the firm, as citizens of the corporate polity. But the firm represents only one kind of intermediate association, that which seeks to produce material wealth or resources beyond the capacities of individuals and their families (non-natural chrematistics). Therefore, the common good of the firm ought to be embedded within a wider common good, that of the political community. The common good of the political community consists in the flourishing (eudaimonia) that each of its citizens or members can achieve, only to the extent that all the other citizens or members achieve it also. As we have seen, this political common good is composed of formal-actual parts, which are irreplaceable, and material-potential parts, which can be substituted by others of a similar nature and quantity. Through its objective dimension, the common good of the firm supplies these material-potential parts of the political common good. The relationship between the common good of the firm and the political common good is best expressed through the principle of subsidiarity. By subsidiarity CST understands that the political community represented by the State should not take over the functions that lower level institutions such as firms are better prepared to fulfil. Rather, States should encourage and promote private initiatives and step in only as a subsidium or help when these falter or are insufficient. The protagonism, therefore, should lie with these lower-level communities. 
Besides integrating the different members of the firm and integrating the firm within the political community, the common good allows for a third, more anthropological level of integration. This has partly been referred to in the subjective dimension of the common good of the firm, the acquisition of skills, virtues and meaning at work, and in the focal point of the political common good or eudaimonia. It lies in the recognition that our highest ambition as human beings (eudaimonia) cannot be achieved individually but only in concert with our fellows and that work is a necessary means to attain it. But work has to be considered not only in its poiesis aspect, directed toward the production of external, material objects, but above all, in its praxis aspect, centering on the qualitative changes it effects in the subject or worker. Work, therefore, is a privileged occasion to develop and to practice all the different excellences or virtues, including theoria or contemplation, which has the divine, transcendent or spiritual for its object. The virtues, particularly those of character, together with different classifications of goods have been the focus, so far, of most Aristotelian business ethics scholarship. For our part, we have striven to underscore how work virtues form a privileged part of the common good and how they effect the integration of the different aspects of human identity: desires, motivations, feelings, reasonings, judgments, actions, habits, characters, roles, situations, organizational cultures and the various "life spheres" of family, work, church and civil society through time. As part of the common good, virtues are like the glue that keeps our identity whole and intact.

In this article we have endeavored to explain how each of the firm's constituents —employees, customers, suppliers, competitors and so forth- participate in the common good of work. We have also shown how each corporate citizen's participation 
in work demands a thorough account of how they can live the different excellences or virtues (subjective dimension), while improving the quality of products, increasing profits and so on (objective dimension). This delves into the conceptual and empirical links between the different virtues at work and their results or outcomes, both at the personal and the institutional or corporate levels. A pending task would be the design of an operational managerial paradigm based on the anthropological, political, economic and ethical premises that the common good provides. A comparison with the other, more established theories of the firm, such as the neoclassical and the (neo-)institutional models would be in order here also. This novel paradigm should be sociologically and historically nuanced, taking into account the different challenges of pre-industrial, industrial and post-industrial or service societies.

\section{References}

Alford, Helen J. and Michael J. Naughton (2001), Managing as if Faith Mattered, Notre Dame, IN: University of Notre Dame Press.

Aristotle (1985), Nicomachean Ethics, trans. Terence Irwin, Indianapolis, IN: Hackett Publishing Company.

Aristotle (1990), The Politics, ed. Stephen Everson, Cambridge: Cambridge University Press.

Boatright, John (2000), Ethics and the Conduct of Business, Upper Saddle River, NJ: Prentice Hall.

Ciulla, Joanne (2000), The Working Life: The Promise and Betrayal of Modern Work, New York: Three Rivers Press.

Clarkson, Max and Deck, Michael (1998), 'Stockholder', In The Blackwell Encyclopedic Dictionary of Business Ethics. Edited by Patricia Werhane and R. Edward Freeman, Malden, MA/Oxford: Blackwell Publishers. 
Crane, Andrew and Matten, Dirk (2004), Business Ethics: A European Perspective, Oxford: Oxford University Press.

Crane, Andrew, Matten, Dirk and Moon, Jeremy (2003), “Can corporations be citizens? Corporate citizenship as a metaphor for business participation in society”, International Center for Corporate Social Resposibility (ICCSR) Research Paper Series, $n^{\circ}$ 13, ISSN 1479-5116.

Donaldson, Thomas and Preston, Lee (1995), 'The stakeholder theory of the corporation: Concepts, evidence, and implications', Academy of Management Review, 20, 65-91.

Freeman, R. Edward (1984), Strategic Management: A Stakeholder Approach, Boston: Pitman.

Friedman, Milton (1970), “The Social Responsibility of Business is to Increase its Profits”, The New York Times Magazine, 13 September.

Hartman, Edwin M. (2008), "Reconciliation in Business Ethics. Some Advice from Aristotle”, Business Ethics Quarterly, 18 (2), 253-265.

Hartman, Edwin M. (2006), “Can We Teach Character? An Aristotelian Answer”, Academy of Management Learning \& Education, 5 (1), 68-81.

Hsieh, Nien-hê (2008), “Survey Article: Justice in Production”, The Journal of Political Philosophy, 16 (1), 72-100.

John Paul II (1981), Encyclical Letter Laborem exercens.

Koehn, Daryl (1995), “A Role for Virtue Ethics in the Analysis of Business Practice”, Business Ethics Quarterly, 5(3), 533-539.

Koehn, Daryl (1999), An Overview of Issues in Corporate Governance, (http://www.stthom.edu/cbes/conferences/daryl_koehn.html), accessed October 16, 2002.

MacIntyre, Alasdair (1985), After Virtue, (2 ${ }^{\text {nd }}$ ed.), London: Duckworth. Manville, Brook and Ober, Josiah (2003), A Company of Citizens. What the World's First Democracy Teaches Leaders about Creating Great Organizations, Boston, MA: Harvard Business School Press. 
Moore, Geoff (2005), “Corporate Character: Modern Virtue Ethics and the Virtuous Corporation”, Business Ethics Quarterly, 15 (4), 659-685.

Pontifical Council for Justice and Peace (2005), Compendium of the Social Doctrine of the Church, Rome: Librería Editrice Vaticana.

Porter, Michael E. (1980), Competitive Strategy, New York: Free Press.

Solomon, Robert C. (1992), “Corporate Roles, Personal Virtues: An Aristotelian Approach to Business Ethics”, Business Ethics Quarterly, 2 (3), 317-339.

Stokes, Geoffrey (2002), 'Democracy and Citizenship’, in April Carter and Geoffrey Stokes (eds), Democratic Theory Today, Cambridge: Polity Press.

Wood, Donna J., Logsdon, Jeanne M., Lewellyn, Patsy G. and Davenport, Kim (2006), Global Business Citizenship. A Transformative Framework for Ethics and Sustainable Capitalism, Armonk, NY/ London, England: M.E. Sharpe. 